\title{
Effects of Human Pancreatic Polypeptide on Exocrine Pancreatic Function in Conscious Rats
}

\author{
Akihiro Funakoshi, Kyoko Miyasaka, ${ }^{*}$ Hirotsugu \\ Shinozaki, Kenichi Kitani, ${ }^{*}$ Naoki Sugiyama $\dagger$ and \\ Haruaki Yajima $\dagger$ \\ The Third Department of Internal Medicine, Kyushu \\ University, Fukuoka 812, * the First Laboratory of Clinical \\ Physiology, Tokyo Metropolitan Institute of Gerontology, \\ Tokyo 173 and $\uparrow$ Faculty of Pharmaceutical Science, Kyoto \\ University, Kyoto 606
}

Funakoshi, A., Miyasaka, K., Shinozaki, H., Kitani, K., Sugiyama, N. and YajIma, H. Effects of Human Pancreatic Polypeptide on Exocrine Pancreatic Function in Conscious Rats. Tohoku J. exp. Med., 1988, 154 (1), 1-9 — The effect of newly synthesized human pancreatic polypeptide (hPP) on pancreatic secretion stimulated by a diversion of bile-pancreatic juice (BPJ) from the intestine, and plasma hPP concentration were examined in conscious rats. Exogenous $\mathrm{hPP}$ infusion $(1,10 \mu \mathrm{g} / \mathrm{kg} / \mathrm{hr})$ inhibited pancreatic protein, bicarbonate and fluid outputs during BPJ diversion in a dose-dependent manner. During 1 and $10 \mu \mathrm{g} /$ $\mathrm{kg} / \mathrm{hr} \mathrm{hPP}$ infusion plasma hPP immunoreactivity increased to $369 \pm 22.9$ and $1,125 \pm 90.2 \mathrm{pg} / \mathrm{ml}$, respectively. These results suggest that newly synthesized hPP has an inhibitory activity on exocrine function of the pancreas.

pancreatic polypeptide; rat pancreas

The effects of pancreatic polypeptide (PP) on pancreatic secretion have been extensively studied, and $\mathrm{PP}$ has been reported to inhibit the basal pancreatic enzyme secretion in humans and dogs, as well as the stimulated enzyme secretion evoked by cholecystokinin (CCK), caerulein, secretin and carbachol (Larsson et al. 1975 ; Adrian et al. 1978a, b; Greenberg et al. 1978, 1979; Lin 1980). PP has a different amino acid sequence in each species, but the biologically active portion lies in its C-terminal amino acid sequence (Kimmel et al. 1984). We have reported the unambiguous solution phase synthesis of a 36-residue peptide amide corresponding to the firmly established amino acid sequence of human PP (hPP) (Sugiyama et al. 1987). As we have established an experimental system to examine pancreatic secretion in the conscious rat (Miyasaka and Green 1984;

Received September 14, 1987 ; revision accepted for publication November 13, 1987.

Address correspondence to: Akihiro Funakoshi, M.D., The Third Department of Internal Medicine, Kyushu University, Maidashi 3-1-1, Higashi-ku, Fukuoka 812, Japan. 
A. Funakoshi et al.

Miyasaka et al. 1986) and radioimmunoassay (RIA) for hPP (Matsumoto et al. 1982), we examined the effect of the exogenous hPP on pancreatic secretion.

\section{Materials and Methods}

Male Wistar rats (308-373 g) were obtained from Shizuoka Jikken Dobutsu (Shizuoka). Rats were prepared with cannulas draining pancreatic juice and bile separately and with a doudenal cannula. The operative procedures used have been described in detail in previous publications (Miyasaka and Green 1984; Miyasaka et al. 1986). In addition, two cannulas were inserted into both the right and the left jugular vein, for continuous infusion of hPP and for drawing blood samples, respectively. After the operation, rats were placed in modified Bollman-type restraint cages and were kept in free access to food and water.

Experiments were conducted after $5 \mathrm{hr}$ of fasting between the $3 \mathrm{rd}$ and 6 th postoperative days. During recovery and between experiments, BPJ was continuously returned to the intestine via a duodenal cannula by a servo-system consisting of a collection tube in a liquid-level photodetector coupled to a peristaltic pump. Animals were maintained in a room with filtered air, a $12 \mathrm{hr}$ light-dark cycle and temperature maintained at $24^{\circ} \mathrm{C}$. One rat was used for each experiment.

\section{Experimental design}

In control animals, bile-pancreatic juice (BPJ) was collected every 30 min period. The volume of pancreatic juice was measured by a Hamilton syringe and $20 \mu \mathrm{l}$ sample was taken for measuring protein and bicarbonate concentrations. Bile was collected in Wintrobe's hematocrit tubing, its volume being measured and mixed with the rest of the pancreatic juice, which was then returned to the intestine by a syringe pump (Harvard Apparatus Compact Infusion Pump, Harvard Apparatus, South Natick, MA, USA) for the next 30 min collection. After a 90 min basal collection with BPJ return to the intestine, BPJ was diverted from the intestine and $0.05 \mathrm{M} \mathrm{NaHCO}_{3}$ was infused instead of BPJ. A $600 \mu \mathrm{l}$ blood sample was drawn through the right jugular vein and the catheter was then flushed with $600 \mu \mathrm{l}$ of isotonic saline before BPJ diversion and at the last point of each $60 \mathrm{~min}$ collection during BPJ diversion. The blood sample was immediately mixed with EDTA $(1.2 \mathrm{mg} \mathrm{EDTA} / \mathrm{ml}$ blood) and aprotinin $(500 \mathrm{KIE} / \mathrm{ml}$ blood) and centrifuged at 3,000 rpm, for $15 \mathrm{~min}$ at $4{ }^{\circ} \mathrm{C}$ for obtaining plasma. Plasma samples were kept at $-20^{\circ} \mathrm{C}$ until PP assay. After a 90 min basal collection, the effect of exogenous $\mathrm{PP}$ on pancreatic secretion was measured during infusion of 1 or $10 \mu \mathrm{g} / \mathrm{kg} / \mathrm{hr}$ of hPP while BPJ was diverted. Blood samples were taken 60-90 min after BPJ diversion. HPP was prepared by one of the authors (Sugiyama et al. 1987), and was dissolved in 1\% BSA-saline solution and infused at a rate of $1 \mathrm{ml} / \mathrm{hr}$.

\section{Laboratory assays}

Bicarbonate concentration was measured by a Natelson microgasometer using a $10 \mu \mathrm{l}$ sample immediately after each collection. Protein concentration was estimated by determing optical density at $280 \mathrm{~nm}$ of samples diluted $1: 200$ times in $0.04 \mathrm{M}$ Tris buffer, $\mathrm{pH} 7.8$ (Keller et al. 1958).

HPP was measured by RIA reported by Matsumoto et al. (1982). Anti-hPP antiserum bound human, bovine and canine PP with equimolar potency, but not rat $\mathrm{PP}$, neuropeptide $\mathrm{Y}(\mathrm{NPY})$ and peptide YY (PYY). HPP immunoreactivity after $\mathrm{hPP}$ infusion in rat plasma was estimated directly without extraction. Plasma dilution curve was paralleled with the standard curve in rat PP-free plasma prepared by $5 \%$ charcoal and nonspecific inhibition by rat plasma components was not observed.

Experimental values were expressed in terms of mean \pm s.E. Results were analyzed by Student's $t$-test and one-way analysis of variance (ANOVA), followed by the Neuman-Keuls 
multiple comparison test. Differences were considered to be significant at $p<0.05$.

\section{RESUlts}

Changes in pancreatic responses to BPJ diversion during PP infusion

BPJ diversion produced significant increases in pancreatic juice flow, bicarbonate and protein outputs as previously reported (Miyasaka and Green 1984). Fluid secretion approached a peak during the 60-90 min collection period after BPJ diversion and was relatively constant thereafter. Bicarbonate and protein outputs peaked during the $60-90 \mathrm{~min}$ collection period and then declined to a value almost twice as high as the basal (BPJ returned) secretion (Fig. 1).

When each dose of hPP was infused in rats with BPJ diversion, the hypersecretion response to BPJ diversion was still substantial. However, fluid secretion slightly declined with time (the last $2.5 \mathrm{hr}$ collection period of the $4 \mathrm{hr}$-BPJ diversion during the infusion of $1 \mu \mathrm{g} / \mathrm{kg} / \mathrm{hr}$ of $\mathrm{hPP}$ compared to each respective collection period in controls without hPP infusion. The infusion of $10 \mu \mathrm{g} / \mathrm{kg} / \mathrm{hr}$

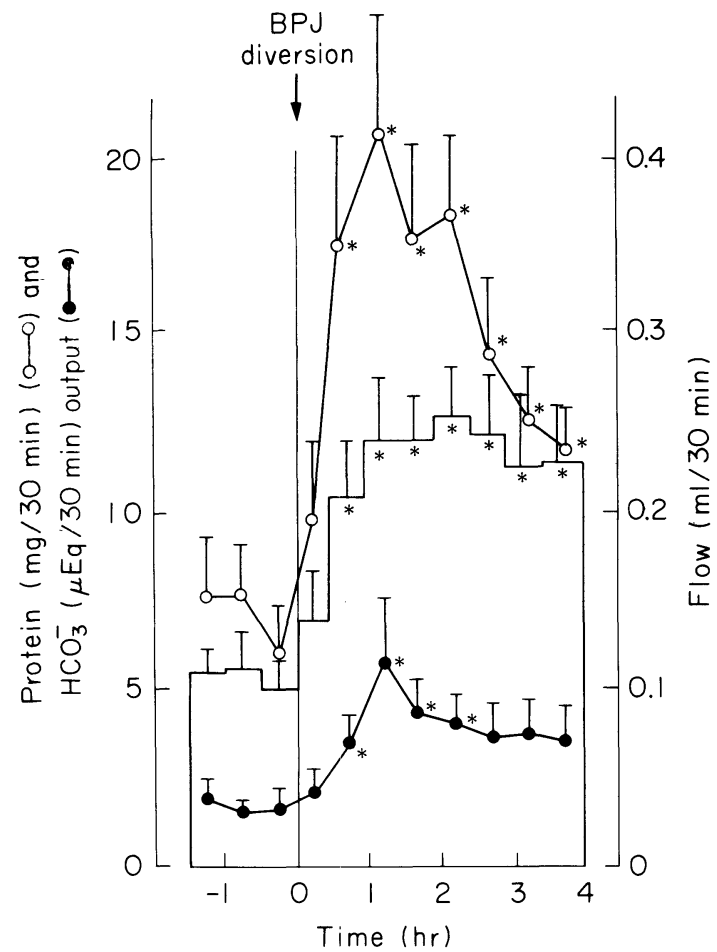

Fig. 1. Pancreatic responses to BPJ diversion. BPJ diversion significantly increased pancreatic juice flow, bicarbonate and protein outputs. $0.05 \mathrm{M}$ $\mathrm{NaHCO}_{3}$ was infused at a rate of $1 \mathrm{ml} / \mathrm{hr}$ instead of BPJ. Values are means \pm S.E. $(n=8)$. Asterisks indicate a significant difference compared with the basal output during the last 30 min collection with BPJ returned, analyzed by Student's $t$-test. 


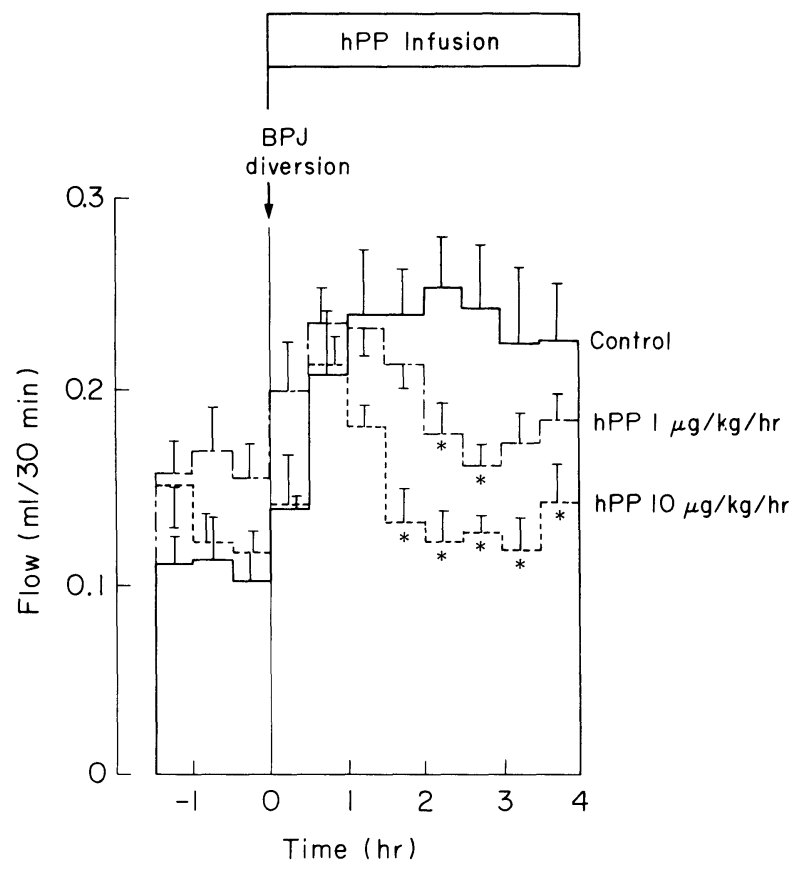

Fig. 2. The pancreatic response of fluid secretion to BPJ diversion with 1 and 10 $\mu \mathrm{g} / \mathrm{kg} / \mathrm{hr}$ of hPP infusion. Fluid secretions slightly decreased with time during the last $3 \mathrm{hr}$ of $4 \mathrm{hr}$ BPJ diversion. 1 and $10 \mu \mathrm{g} / \mathrm{kg} / \mathrm{hr}$ of $\mathrm{hPP}$ infusion significantly suppressed fluid secretion compared to controls (without PP infusion). ${ }^{*} p<0.05$ against controls $(n=8$ for $1 \mu \mathrm{g} / \mathrm{kg} / \mathrm{hr}$ of $\mathrm{hPP}$ infusion, $n=7$ for $10 \mu \mathrm{g} / \mathrm{kg} / \mathrm{hr}$ of hPP infusion).

of hPP showed a marked inhibitory effect on fluid output during the last $2.5 \mathrm{hr}$ collection of BPJ diversion (Fig. 2). The protein (Fig. 3) and the bicarbonate output (Fig. 4) changed almost in parallel with the fluid output.

Incremental pancreatic fluid, bicarbonate and protein outputs above basal during the BPJ diversion are shown in Table 1. Values were calculated as follows : the average value per hr of fluid, bicarbonate and protein outputs during the first $3 \mathrm{hr}$ of the $4 \mathrm{hr}$ period of BPJ diversion, minus the average value of each component during the last twice basal collection periods. Increments of fluid, bicarbonate and protein outputs were inhibited by hPP infusion in a dose dependent manner which were significant by ANOVA. The infusion of hPP (10 $\mu \mathrm{g} / \mathrm{kg} / \mathrm{hr}$ ) significantly inhibited fluid, bicarbonate and protein outputs, and the infusion of hPP $(1 \mu \mathrm{g} / \mathrm{kg} / \mathrm{hr})$ significantly inhibited fluid and protein outputs as evaluated by Neuman-Keuls multiple comparison test, respectively.

\section{Plasma hPP immunoreactivity level during hPP infusion}

Plasma hPP concentrations 60 min after the beginning of hPP infusion were as follows : $369 \pm 22.9 \mathrm{pg} / \mathrm{ml}, n=8$, mean \pm s.E. for $1 \mu \mathrm{g} / \mathrm{kg} / \mathrm{hr} \mathrm{hPP}$ infusion and 


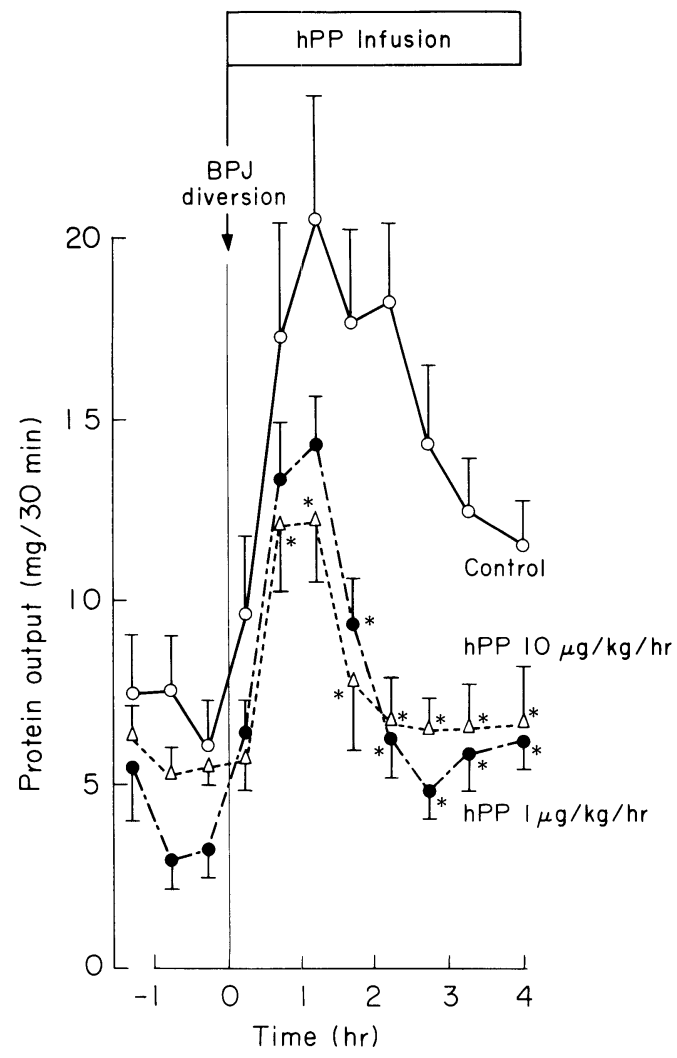

Fig. 3. The pancreatic response of protein secretion to BPJ diversion with 1 and $10 \mu \mathrm{g} / \mathrm{kg} / \mathrm{hr}$ of hPP infusion. Values were obtained from the same material as shown in Fig. 2. Protein output was significantly inhibited during the last $2 \mathrm{hr}$ period of $4 \mathrm{hr}$ BPJ diversion by PP infusion. Marks and symbols are the same as in Fig. 2.

$1125 \pm 90.2 \mathrm{pg} / \mathrm{ml}, n=6$ for $10 \mu \mathrm{g} / \mathrm{kg} / \mathrm{hr} \mathrm{hPP}$ infusion. Thereafter the plasma $\mathrm{hPP}$ concentration was maintained at an almost constant level during hPP infusion (Fig. 5).

\section{Discussion}

Human, bovine, canine, porcine, and ovine pancreatic polypeptides differ among one another in only one or two amino acid residues (Lin 1980). Recently, the structure of rat $\mathrm{PP}$ has been elucidated. The amino acid sequence differs significantly from PP of other mammals, although their C-terminal hexapeptides are identical (Kimmel et al. 1984). Thus, it was not known whether hPP has biological actions in the rat.

In the present study, as low as $1 \mu \mathrm{g} / \mathrm{kg} / \mathrm{hr} \mathrm{hPP}$ which raised plasma $\mathrm{PP}$ concentration into the physiological range observed in postprandial condition (Floyd et al. 1977), significantly inhibited pancreatic juice flow and protein 


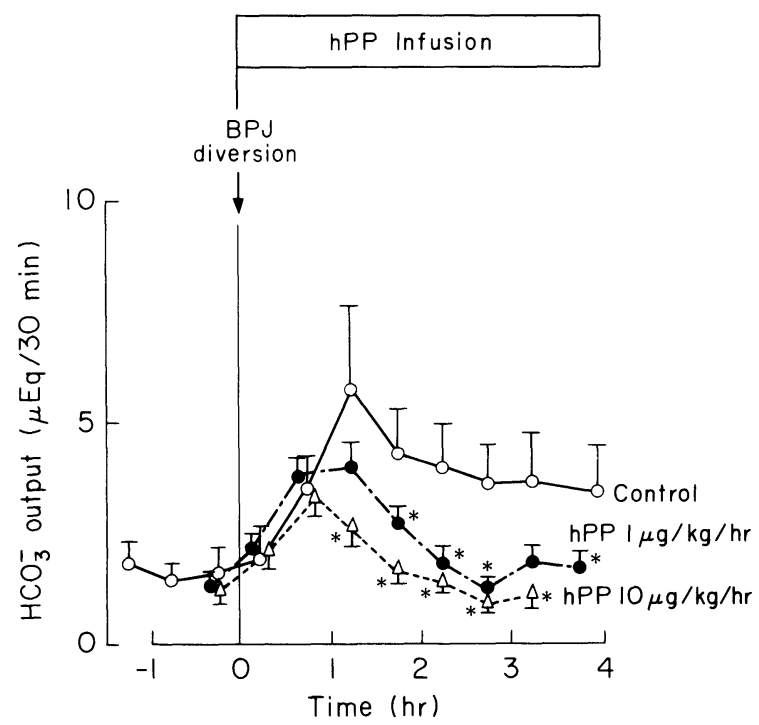

Fig. 4. The pancreatic response of bicarbonate secretion to BPJ diversion with 1 and $10 \mu \mathrm{g} / \mathrm{kg} / \mathrm{hr}$ of hPP infusion. Values were obtained from the same materials as in Fig. 2. Bicarbonate output was significantly inhibited during the last $2 \mathrm{hr}$ period of $4 \mathrm{hr}$ BPJ diversion by PP infusion. Infusion of hPP at a rate of $10 \mu \mathrm{g} / \mathrm{kg} / \mathrm{hr}$ produced a greater inhibitory effect than $1 \mu \mathrm{g} / \mathrm{kg} / \mathrm{hr}$ of hPP infusion. Marks and symbols are the same as in Fig. 2.

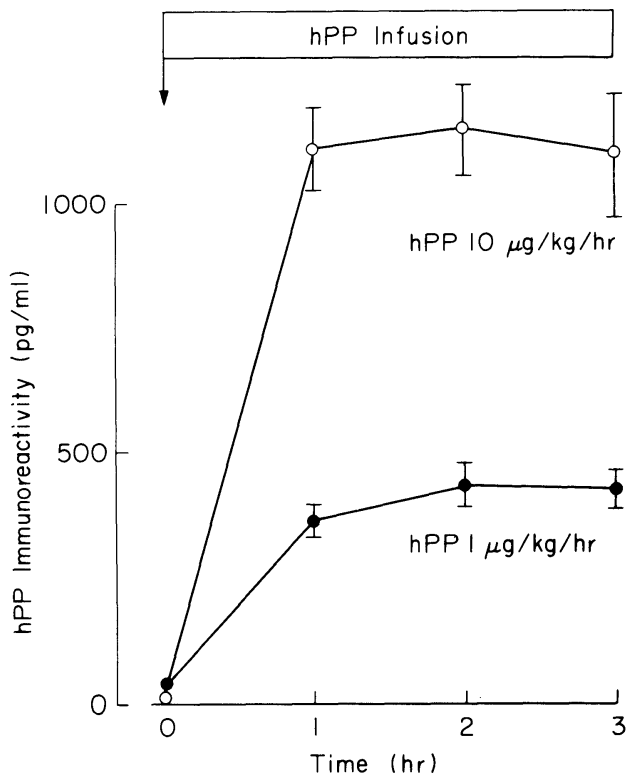

Fig. 5. Changes in plasma hPP immunoreactivity during $1(n=8)$ and $10 \mu \mathrm{g} / \mathrm{kg} /$ hr $(n=6)$ hPP infusion. Plasma hPP level was increased after hPP infusion and maintained almost the same level during hPP infusion. 
output, and slightly inhibited bicarbonate output. This observation suggests that PP may be important in the physiological regulation of pancreatic function. Exogenous hPP of as much as $10 \mu \mathrm{g} / \mathrm{kg} / \mathrm{hr}$ significantly decreased not only fluid secretion and protein output but also the bicarbonate output. However, this must be a pharmacological effect as indicated by plasma hPP concentration during hPP infusion.

No receptors for $\mathrm{PP}$ on the pancreatic acinar cells in the rat could be demonstrated (Louie et al. 1985), and it was suggested that the indirect mechanism was involved in the action of PP (Louie et al. 1985). Therefore, the mechanism of inhibitory effect of $\mathrm{PP}$ on pancreatic exocrine secretion is considered to be indirect. It was also reported that other inhibitory agents, such as PYY, NPY and somatostatin could not inhibit pancreatic secretion in isolated acini (Louie et al. 1985 ; Singh 1986), although the receptor for somatostatin on acinar cells was recently defined (Strikant 1986). We have reported an experimental system for determining pancreatic exocrine secretion in conscious rats (Miyasaka and Green 1984 ; Miyasaka et al. 1986). One of the most important utilities of our experimental system is that it can study the inhibitory effect of these agents. Since the pancreatic secretion in the intestinal phase is regulated by luminal feedback in the rat (Green and Lyman 1972), we can observe the inhibitory effect of an agent during pancreatic hypersecretion by BPJ diversion. Moreover, a conscious rat secrets 10-fold more pancreatic juice than anesthetized rat (Petersen and Grossman 1977). The exact mechanism of the feedback regulation has not been elucidated, but it has been shown that CCK is released when protease activities are removed in the proximal intestine decreased below the threshold (Louie et al. 1986). Louie et al. (1985) examined the effect of PP on pancreatic secretion in the

TABLE 1. Incremental outputs of fluid, bicarbonate and protein during bilepancreatic juice diversion with or without human pancreatic polypeptide infusion (hPP)

\begin{tabular}{llcc}
\hline & Fluid $(\mathrm{ml} / \mathrm{hr})$ & $\mathrm{HCO}_{3}(\mu \mathrm{Eq} / \mathrm{hr})$ & Protein $(\mathrm{mg} / \mathrm{hr})$ \\
\hline $\begin{array}{c}\text { Control } \\
(n=8)\end{array}$ & $0.224 \pm 0.032$ & $4.34 \pm 1.02$ & $20.46 \pm 2.66$ \\
$\begin{array}{c}\mathrm{hPP} 1 \mu \mathrm{g} / \mathrm{kg} / \mathrm{hr} \\
(n=8)\end{array}$ & $0.099 \pm 0.022^{*}$ & $3.86 \pm 0.42$ & $11.47 \pm 1.76^{*}$ \\
$\begin{array}{c}\mathrm{hPP} 10 \mu \mathrm{g} / \mathrm{kg} / \mathrm{hr} \\
(n=7)\end{array}$ & $0.072 \pm 0.037^{*}$ & $1.38 \pm 0.59^{*}$ & $7.59 \pm 2.41^{*}$ \\
\hline
\end{tabular}

Analysis by ANOVA

Increment of fluid output:

$\mathrm{F}(2.20)=7.03, \quad p<0.01$

Increment of $\mathrm{HCO}_{3}^{-}$output:

$\mathrm{F}(2.20)=4.41, \quad p<0.05$

Increment of protein output:

$\mathrm{F}(2.20)=8.17, \quad p<0.01$

Values are means \pm s.E. ${ }^{*} p<0.05$ against corresponding control values by Neuman Keuls. 
anesthetized rat and observed that $20 \mu \mathrm{g} / \mathrm{kg} / \mathrm{hr}$ bovine PP caused the maximal inhibition of CCK stimulated pancreatic secretion and that even rat PP $(40 \mu \mathrm{g} /$ $\mathrm{kg} / \mathrm{hr}$ ) inhibited CCK-33 induced bile-pancreatic protein output by $20 \%$. However, in the present experiments, as little as $1 \mu \mathrm{g} / \mathrm{kg} / \mathrm{hr}$ of $\mathrm{hPP}$ inhibited protein output by $55 \%$ (Table 1 ). This difference could be attributed to the difference between an anesthetized and conscious animal. Therefore, again we would like to emphasize the importance of the use of non-anesthetized animals in examining the physiological role of this kind of inhibitory hormones.

In summary, hPP can inhibit pancreatic exocrine secretion stimulated by BPJ diversion in the rat within the physiological plasma concentration of PP. This suggests that C-terminal hexapeptide of the PP molecule has the biological activity in the rat.

\section{References}

1) Adrian, T.E., Besterman, H.S., Mallinson, C.N., Greenberg, G.R. \& Bloom, S.R. (1978a) Inhibition of secretin stimulated pancreatic secretion by pancreatic polypeptide. Gut, 20, 37-40.

2) Adrian, T.E., Greenberg, G.R., Besterman, H.S. \& Bryant, M.G. (1978b) PP infusion in man-summary of initial investigation. In: Gut Hormones, edited by S.R. Bloom, Churchill Livingstone, Edinburgh-London-New York, pp. 254-260.

3) Floyd, J.C., Fajans, S.S., Pek, S. \& Chance, R.E. (1977) A newly recognized pancreatic polypeptide; plasma levels in health and disease. Recent. Prog. Horm. Res., 33, 519-570.

4) Green, G.M. \& Lyman, R.L. (1972) Feedback regulation of pancreatic enzyme secretion as a mechanism for trypsin inhibitor-induced hypersecretion in rats. Proc. Soc. exp. Biol. Med., 140, 6-12.

5) Greenberg, G.R., McCloy, R.F., Chadwick, V.S., Adrian, T.E., Baron, J.H. \& Bloom, S.R. (1978) Inhibition of pancreas and gallblandder by pancreatic polypeptide. Lancet, 2, 1280-1282.

6) Greenberg, G.R., McCloy, R.F., Chadwick, V.S., Adrian, T.E., Baron, J.H. \& Bloom, S.R. (1979) Effect of bovine pancreatic polypeptide on basal pancreatic and biliary outputs in man. Amer. J. dig. Dis., 24, 11-14.

7) Keller, P.J., Cohen, E. \& Neurath, H. (1958) The proteins of bovine pancreatic juice. J. biol. Chem., 233, 344-349.

8) Kimmel, J.R., Pollack, H.G., Chance, R.E., Johnson, M.G., Reeve, J.R., Taylor, I.L., Miller, C. \& Shively, J.E. (1984) Pancreatic polypeptide from rat pancreas. Endocrinology, 114, 1725-1731.

9) Larsson, L.I., Sundler, F. \& Hakanson, R. (1975) Immunohistochemical localization of human pancreatic polypeptide (HPP) to a population of islet cell. Cell Tissue Res., 156, 167-171.

10) Lin, T.M. (1980) Pancreatic polypeptide isolation, chemistry, and biological function. In : Gastrointestinal Hormones, edited by G.B.J. Glass, Raven Press, New York, pp. 275-306.

11) Louie, D.S., Williams, J.A. \& Owyang, C. (1985) Action of pancreatic polypeptide on rat pancreatic secretion: in vivo and in vitro. Amer. J. Physiol., 24, G489-495.

12) Louie, D.S., May, D., Miller, P. \& Owyang, C. (1986) Cholecystokinin mediates feedback regulation of pancreatic enzyme secretion in rats. Amer. J. Physiol., 250, G252-259.

13) Matsumoto, M., Wakasugi, H. \& Ibayashi, H. (1982) Plasma human pancreatic 
polypeptide response in chronic pancreatitis. Gastroenterol. jap., 17, 25-30.

14) Miyasaka, K. \& Green, G.M. (1984) Effect of partial exclusion of pancreatic juice on rat basal pancreatic secretion. Gastroenterology, 86, 114-119.

15) Miyasaka, K., Kitani, K. \& Green, G.M. (1986) The sequential changes in pancreatic exocrine function after abdominal surgery in the rat. Pancreas, 1, 347-353.

16) Petersen, H. \& Grossman, M.I. (1977) Pancreatic exocrine secretion in anesthetized and conscious rats. Amer. J. Physiol., 233, E530-536.

17) Singh, M. (1986) Effect of somatostatin on amylase secretion from in vivo and in vitro rat pancreas. Dig. Dis. Sci., 31, 506-512.

18) Strikant, C.B. (1986) Somatostatin receptors on rat pancreatic acinar cells. J. biol. Chem., 261, 7690-7696.

19) Sugiyama, N., Fujii, N., Funakoshi, S., Funakoshi, A., Miyasaka, K., Aono, M., Moriga, M., Inoue, K., Kogire, M., Sumi, S., Doi, R., Tobe, T. \& Yajima, H. (1987) Studies on peptides CLIV. Synthesis of a 36-residue peptide amide corresponding to the entire amino acid sequence of human pancreatic polypeptide. Chem. Pharm. Bull., 35, $3585-3596$. 